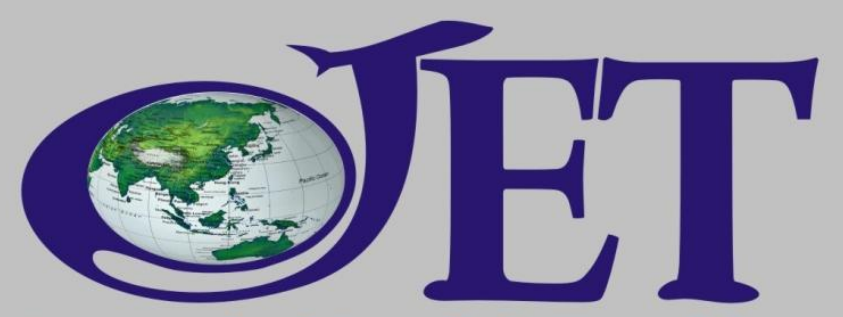

Journal of English Teaching a

triannual

publication

on the study of

English Language Teaching

Volume 1, Number 1, February 2011

\title{
Students' Perception on EFL Speaking Skill Development
}

\author{
Situjuh Nazara \\ Christian University of Indonesia \\ Jakarta, Indonesia \\ c7nazara@gmail.com
}

\begin{abstract}
This paper is based on a study conducted in December 2010 to investigate the perceptions of the students of the English Teaching Study Program of FKIPUKI Jakarta on their English speaking skill development. The findings revealed that all respondents viewed speaking important and they were willing to deal with the necessities to master it. Although they got interesting materials, empowering activities, and proper opportunity to practice speaking, they insisted to have longer time to practice. In addition, some respondents tended to avoid speaking due to their fear of lecturers' 'scolding' and classmates' laughing. The paper concludes by suggesting the need to create a friendly and conducive environment in the classroom.
\end{abstract}

Keywords: EFL, speaking skill, students' perception, speaking classes 


\section{Introduction}

Along the history of foreign language teaching and learning, speaking has always been considered as the most essential skill to be mastered for several reasons. First, approaches and methods for teaching speaking have long been major focuses of language teaching researches and conferences. Second, a huge number of conversation and other speaking course books, audios and videos are continuously published. In addition, many language learners regard speaking ability as the measure of knowing a language. They define fluency as the ability to converse with others, much more than the ability to read, write, or comprehend oral language. They regard speaking as the most important skill they can acquire.

At present, the need for speaking mastery in English has been dramatically increasing due to the strengthening position of English as a language for international communication. Its use as the working language in $85 \%$ of international organizations (Crystal 1997) and its function as the main gate to get a better job, especially in multinational companies have motivated a great number of people around the world to learn English as a second language (henceforward ESL) or and as a foreign language (henceforward EFL) in order to be able to speak in it. Graves (2008) accentuates "the purposes of learning a language in TL-removed contexts are varied, but the thrust is to learn language to communicate, to improve one's economic prospects, to expand one's horizon's both literally and/or figuratively to be a global citizen" (p. 156). In relation to this, Richards and Renandya's (2002) assert: "A large percentage of the world's language learners study English in order to develop proficiency in speaking" (p. 201). The tendency to prioritize the mastery of speaking is also reflected in the tendency of society to make speaking skills as a measure of one's mastery of English. In fact, many students consider language fluency to communicate verbally with others is often considered more important than the ability to read or write. They argue that speaking is the most important language skills that need to be controlled, and they assess learning achievement based on mastery of speaking skills (Burnkart, 1998).

Realizing the high importance of speaking skill in EFL programs, it is very important to find and use the best instructional methods, materials, activities, media, and other requirements that will help the learners master speaking skill. However, although a great number of studies aimed to help learners master speaking skill has been conducted, many EFL learners still find speaking it very difficult to master. In addition to the view that speaking is "the most complex and difficult skill to master" (Hinkel, 2005, p. 485), another cause is possibly that those studies still mainly dealt with the linguistic aspects of second language acquisition. Little research has been carried out regarding students' perspectives on the learning of speaking in the EFL classroom, 
whereas students' views - which at least provide awareness to teachers in this context - is an important aspect to be considered.

This paper discusses the findings of a study recently conducted to investigate the students' perceptions on their English speaking skill development at the English Teaching Study Program of the Faculty of Education and Teachers Training of the Christian University of Indonesia (henceforward FKIP-UKI) Jakarta.

\section{Literature Review}

Speaking is a multifaceted construct. Thornbury and Slade (2006) point out that this complexity derives from speaking being so ubiquitous in our daily language usage (p. 5). In other words, speaking is so intertwined with daily interactions that it is difficult to define. In addition, various fields of studylinguistics, psychology, anthropology, and sociology-have informed speaking. (Gumperz, 1999, p. 98). It therefore becomes harder to compile a concise yet comprehensive definition of speaking. The best we can do is to define speaking by its feature, its functions and its conditions.

Viewing from its feature, speaking could be defined as a social, multisensory speech event, whose topic is unpredictable. Speaking is social, in the sense that it establishes rapport and mutual agreement, maintains and modifies social identity, and involves interpersonal skills (Thornbury and Slade, 2006, p. 17). This social element is expressed through wishes, feelings, attitudes, opinions and judgments, which can clash with the formal nature of the classroom when teaching speaking.

According to Gumperz (1999), speaking is cooperatively constructed which is based on contributions, assumptions, expectations, and interpretations of the participants' utterances (p. 101). Since it is cooperative, it becomes a negotiated, self-regulated process (Nunan, 1999, p. 226; Sayer, 2005, p. 17) that is segmentally created through short, frequent turns consisting of phrases and clauses (Thornbury and Slade, 2006, p. 13). This cooperative discourse is motivated by interactive rules and routines (Dornyei and Thurrell, 1994, p. 42) where these structures guide how silence, volume, intonation, conventional language, information and norms of interaction are used (Applegate, 1975) to organize speaking. This organization is culture-bound as conversational routines are implemented differently in different countries (Richards, 1980, p. 419). Dornyei and Thurrell (1994) highlight the features of conversational routines as being openings and closings, turn-taking mechanisms and adjacency pairs such as greetings and apologies.

Speaking is also a multi-sensory activity because it involves paralinguistic features such as eye-contact, facial expressions, body language, tempo, pauses, voice quality changes, and pitch variation (Thornbury, 2005, p. 9) which affect conversational flow. It seems that culture is integral in how 
speaking is constructed which has implications for how English speaking is taught and learned.

In addition, speaking is topically unpredictable and therefore native speakers tend to have a "linguistic repertoire" of regularly used phrases (Gumperz, as cited in Yorio, 1980, p. 434) that help create various speaking. In relation to the teaching of speaking, these rules, routines, and linguistic features would be valuable to highlight in a speaking class.

Based on its function, speaking is defined as a way to verbally communicate for mostly interpersonal and somewhat transactional purposes (Nunan, 1999, p. 228). Interactional language engages people for social reasons as illustrated previously. Transactional language is for service encounters like ordering drink or booking a ticket. However, these purposes are usually intertwined (Thornbury and Slade, 2006, p. 20) and so the distinction between interactional and transactional language seems to be used for language learning awareness.

Viewing from the condition when it takes place, speaking usually happens when people are face-to-face (Van Lier, 1989, p. 492), which makes it highly interactional and social. However, Thornbury and Slade (2006, p. 23) point out that 'computer-mediated communication' shares many conversational characteristics where face-to-face may not be the only way to have a conversation. Speaking happens in a small group of people with a minimum of two. It happens within shared contexts such as in situational, institutional, social and cultural environments (Thornbury and Slade, 2006, p. 15). Speaking take places in real time and demands spontaneous decision-making and improvisation leading to a very dynamic discourse (VanLier, 1989, p. 493; Nunan, 1999, p. 226).

In summary, speaking is a specific spoken discourse that is primarily social and engaged in for social purposes and in social contexts. It entails three areas of knowledge (Burnkart, 1998). First, the mechanical elements of language (pronunciation, grammar, and vocabulary), which allows the speaker to use the right words in the correct sequence and appropriate pronunciation. Second, the speaking functions (transaction and interaction), which enables the speaker to know when the clarity of the message is needed (as in carrying out the transaction or in exchanging of information) and when a deep understanding is not necessary (as in the development of relations). Third, the sociocultural norms (such as turn-taking, rate of speech, length of pauses between speakers, relative roles of participants) which enable an individual to realize the conversational situation, whom he is talking to, and what the purpose of speaking is. By understanding these elements, an individual will know when he takes a turn to speak and when to listen, how quickly he should speak, and how long he should pause. 
In relation to language teaching, Applegate (1975) stresses that "communication can only be effective when the student is sensitive to the social and cultural aspects of language use and how these differ between his first and second language" (p. 271). Speaking classes must be guided by the elements of conversation as previously mentioned and the means to generate genuine conversation. In other words, to succeed speaking classes, the uses of correct approach, interesting activities, proper equipments, and high motivation are necessary.

Up to the present days, there are three well known approaches in the teaching of speaking in a second or a foreign: the indirect approach, direct approach and indirect approach plus (Kroeker, 2009). The indirect approach is based on the idea that speaking skill is formed through students' active participation in interactive activities such as discussion, role-play, information gaps, and problem-solving activities (Dornyei \& Thurrell, 1994, p. 41). This approach is applied in some language teaching methods, such as the Audiolingual Method, Community Language Learning, and Communicative Language Teaching. It is assumed that if the interactions carried out are meaningful, students speaking proficiency will grow (Brown, 2001, p. 276). However, Nunan (1999, p. 240) states that interactive activities tend to bring up reproductions of utterances rather than meaningful expressions. The indirect approach is considered less structured and more appropriate for upper level students. Nevertheless, this approach is able to meet the student's desire to practice the speaking skills they already master.

The direct approach is based on information about a systematic program of micro skills, communication strategy, language input, and processes that lead to fluent speaking, which is informed by speaking analysis, second language acquisition and discourse analysis (Dornyei and Thurrell, 1994, p. 40). According to Brown (2001, p. 277), the direct approach could be very effective if the explicit teaching of aspects of speaking is combined with the opportunity to practice. This approach includes recording speaking to recognize student deficiencies in observing real speaking transcripts (Sayer, 2005, p. 15), good speaker (Cane, 1998, p. 36), and the differences between non-native and native speaking (McCarthy, 1991, p. 121). In Skehan's (as cited in Thornbury and Slade, 2006, p. 222) view, however, this approach seems to over-rely on skills and strategies at the expense of linguistics and the teaching of unnecessary functional language in particular contexts. Cook (1989) adds that not everything about speaking can be taught because some mechanisms are only unconsciously accessible like pausing, overlapping, and pitch rise to signal turn-taking ( $\mathrm{p}$. 117).

The 'indirect plus approach' is a combination of learner-centered training, language exposure, interactional activities and teaching speaking as a spoken discourse (Thornbury and Slade, 2006, p. 295). Seeing from its 
elements, this approach looks similar to the 'principled communicative approach' (Celce-Murcia et al, 1997, p. 148) and Willis' (1996) 'task-based approach'. They are characterized as highlighting specific language input and exposure to real speaking with consciousness-raising time in systematically sequenced activities. Explicit teaching is punctuated at strategic points in the lesson. Rearrangements of exposure, instruction and practice are its underlying elements. Teaching starts with teacher-student collaboration on concerns, needs, and abilities that generate the conversational content. This approach is seen to demand much teacher practice and skill nurturing (Gibbons, as cited in Thornbury and Slade, 2006, p. 313), learner-centered training and much motivation to collaborate in classroom decisions. However, Thornbury (1998, p. 110) remarks that classrooms and textbooks are still widely grammar-driven which makes any conversational approach difficult to apply.

In addition to the right approach, speaking classes also require a variety of facilities (textbooks and audiovisual media), activities, adequate training, and opportunities to interact with the target language. Nunan (1999, p. 241) emphasizes that in speaking classroom learners should be given the maximum number of opportunities to practice the target language in meaningful contexts and situation. The opportunities are an integral part of a speaking class. The main task of an instructor is to assist the student master the mechanical elements of language (pronunciation, grammar, and vocabulary), elements of language functions, and elements of sociocultural norms by providing an authentic exercises that prepares them to interact in real communication. Instructors need to help students produce grammatical expressions, logical, and according to the situation of the speaking, and using an acceptable pronunciation.

The present study was conducted to investigate the perceptions of the students of the English Teaching Study Program of FKIP-UKI Jakarta on their English speaking skill development. Results of many studies have indicated that students' perception play a great role in every language teaching and learning process. In the context of speaking classes, how the teachers/lecturers work with the students, how they motivate speech activities, and relate them to their personal interests and needs, are vital factors for the improvement of speech. Thus, in order to succeed speaking classes in the English Teaching Study Program of FKIP-UKI, students' views need to be considered. Lecturers' awareness of students' belief in this context will surely beneficial in designing the strategies and activities for the promotion of speaking skill. 


\section{Methodology}

This study employed the explanatory mixed method design which enables us to gather qualitative input to explain and extend quantitative results in order to gain a comprehensive insight of the research (Creswell et al., 2003). A '16 item questionnaire' was administered to obtain quantitative input and constructed to determine the students' perceptions on EFL Speaking development. Before it was used to collect the data, the questionnaire was tested in a preliminary pilot study conducted with five students. The pilot study served to see whether the wording of the questions was clear and the completion of the tasks was feasible. Minor changes were introduced in the original plan as a result of this process.

The data were collected at the end of the odd semester of Academic Year 2010/2011 (December 2010). The respondents were 40 students randomly selected from the fifth and the seventh semester students of the English Teaching Study Program of FKIP-UKI. The reason for limiting the sample only to the fifth and the seventh semester students was that since they had passed Speaking classes (Speaking I, II, III, and IV) they would find no difficulty to properly respond to the questionnaire.

To enrich and support the quantitative findings, a focused semi structured open-ended interview was also employed. The themes that emerged during the interview sessions were coded in accordance to the quantitative dimensions from the questionnaire. 20-25 minute interview sessions were conducted with 5 volunteers, who were respondents to the questionnaire administered. The rationale for using focused semi structured open-ended interviews was to understand the respondents' point of view rather than make generalizations. As in all such interviews, the researchers set the focus of the interview.

\section{Results and Discussion}

The sixteen items included in the questionnaire can be divided into five sections. The first statement concentrates on students' belief in their speaking mastery level. The next two statements center on students' eagerness to develop their speaking. The fife statements included in the third section deal with students' view on opportunities and time they had for practicing speaking. The three statements in the fourth section focus on students' perceptions on speaking classes' materials, activities and facilities. The last section, which includes five statements, concentrates on students' view on classroom climate and psychological obstacles.

The findings related to the respondents' perception on their belief in their speaking mastery level (as shown in table 1) revealed that $45 \%$ of them believed their speaking mastery is high, and the rest 55\% denied this. This 
finding is a bit surprising, because there were more respondents who viewed their speaking skill unsatisfactory than those who viewed it satisfactory. Although it was possible that some of the respondents chose "No" for this item due to their tendency to be modest, as indicated by the qualitative data related to this dimension, this finding needs to be seriously considered by the study program while arranging its strategic plan. Programs for enhancing students' speaking skill need to be made one of the priorities.

Table 1: Respondents' Belief in their Speaking Mastery Level

\begin{tabular}{|c|l|c|c|}
\hline No. & \multicolumn{1}{|c|}{ Statement } & Yes & No \\
\cline { 3 - 4 } 1 & $\begin{array}{l}\text { Respondents' speaking mastery } \\
\text { is high }\end{array}$ & $\mathbf{f}(\boldsymbol{\%})$ & $\mathbf{f}(\mathbf{\%})$ \\
\hline
\end{tabular}

Well, most people with whom I communicate in English can catch what I mean. So, I think my speaking skills are good enough. But, you know, I don't think it's always easy to express my idea, I think my speaking skills are not yet high. (Interviewee A)

It's always difficult to rate your own skill. But, by considering that I still sometimes find it difficult to use good pronunciation, I don't think my speaking mastery is high. Uh huh, just moderate, I guess. (Interviewee B)

Well, it's a bit difficult to answer. But coz I find no significant problems any time I communicate in English, you can say my speaking ability is quite high. Yeah. (Interviewee C)

The distribution of the respondents' eagerness to develop speaking skill (as shown in table 2) revealed that $100 \%$ of them wanted to speak English well and fluently. This finding was in line with the finding that more than a half of them $(55 \%)$ were willing to be one of the speakers in the seminar or other programs requiring speaking skill held by the English Teaching Study Program. The finding that the number of respondent who denied their speaking skill is high (i.e. 55\%) was equal to the number who were willing to be one of the speakers in the seminars or to join speech contests and debate competitions. Thus, it was highly probable that the respondents saw presenting a paper at a seminar and other similar programs a good challenge to develop their speaking skill. The data obtained through interviews strengthen these findings, as indicated in the following excerpts. 
Table 2: Respondents' Eagerness to Develop Speaking Skill

\begin{tabular}{|c|l|c|c|}
\hline \multirow{2}{*}{ No. } & \multicolumn{1}{|c|}{ Statements } & \multicolumn{1}{|c|}{ Yes } & \multicolumn{1}{|c|}{ No } \\
\cline { 3 - 4 } 1 & $\begin{array}{l}\text { f(\%) } \\
\text { Eagerness to speak English well and } \\
\text { fluently. }\end{array}$ & $40(100)$ & $0(0)$ \\
\hline & $\begin{array}{l}\text { Willingness to be one of the speakers } \\
\text { in the seminar, speech contests, } \\
\text { debating, and other programs requiring } \\
\text { speaking skill held by the English } \\
\text { Teaching Study Program. }\end{array}$ & $22(55)$ & $18(45)$ \\
\hline
\end{tabular}

Yes. To speak English well and fluently is certainly my major objective in learning English. I'm ready to do everything to achieve it, including being a speaker in a seminar. (Interviewee A)

Yes. I am here to study, to speak English well and fluently. You know, I'll do my best if I were given the opportunity to present papers at seminars. (Interviewee B)

Absolutely yes! Speaking is the main skill I'd like to master. Daily practices with fellow students and interacting with a native speaker are activities I always do to develop my speaking skill. Presenting a paper at seminars? I think it would be interesting and challenging as well. (Interviewee D)

Well, I think all language skills are important to master. However, speaking should be made a priority. The first thing people see in you is speaking. That's why I really want to be able to speak well and fluently. ... To be a speaker in a seminar, with hundreds of audience? Wait a minute. It demands too much, I think. I'd rather be a participant, I guess. (Interviewee $\mathrm{E}$ )

Table 3 reveals that $28(70 \%)$ respondents said that they got appropriate opportunity for improving speaking in speaking classes, whereas 12 (30\%) respondents denied in this connection. Despite the appropriate opportunity for speaking improvement, $90 \%$ of them, however, responded that the time provided for practicing speaking in speaking classes is too limited. This is supported by the finding that $77.5 \%$ of them suggested that the time for practicing speaking in speaking classes should be lengthened. The contradiction between the appropriate opportunity for speaking improvement and the necessity to lengthen the time for practicing was probably caused by the 
relatively big number of students (30 to 35 students) in each speaking classes. In relation to this, speaking lecturers should be more creative to create in employing more suitable class management and activities that provides longer time for every student to practice speaking. Assigning students to discuss interesting topics in pair or group work (up to three students) is possibly a good alternative. Dealing with thirty students in a speaking class is tough. But dealing with fifteen pairs or ten groups of three will make the classroom more manageable and every student keep being active.

When asked whether the opportunity to enhance speaking skills provided by lectures in non-speaking classes was proper, $60 \%$ respondents replied that it was so, while $40 \%$ were of the opinion that such was not the case. This is in line with the finding that $67.5 \%$ of the respondents agreed with the idea of providing more intensive use of English in non-speaking classes. It seems that for them all classes, including non-speaking classes, should also be utilized to develop speaking skills. Thus, non-speaking classes should employ more interactive way of learning in order to provide the students with greater opportunity for practicing speaking skill. In other words, non-speaking-class lecturers need to optimize the use of speaking as tool for thinking and learning.

Table 3: Opportunity and Time for Practicing Speaking

\begin{tabular}{|c|c|c|c|}
\hline \multirow{2}{*}{ No. } & \multirow{2}{*}{ Statements } & Yes & No \\
\hline & & $f(\%)$ & $f(\%)$ \\
\hline 1 & $\begin{array}{l}\text { Appropriate opportunity for } \\
\text { improving speaking in } \\
\text { speaking classes. }\end{array}$ & $28(70)$ & $12(30)$ \\
\hline 2 & $\begin{array}{l}\text { The time provided for } \\
\text { practicing speaking in } \\
\text { speaking classes is too limited. }\end{array}$ & $36(90)$ & $4(10)$ \\
\hline 3 & $\begin{array}{l}\text { The time provided for } \\
\text { practicing speaking in } \\
\text { speaking classes should be } \\
\text { lengthened. }\end{array}$ & $31(77.5)$ & $9(22.5)$ \\
\hline 4 & $\begin{array}{l}\text { Proper opportunity to develop } \\
\text { speaking skills provided by } \\
\text { lectures in non-speaking } \\
\text { classes. }\end{array}$ & $24(60)$ & $16(40)$ \\
\hline 5 & $\begin{array}{l}\text { Necessity for having more } \\
\text { intensive use of English in } \\
\text { non-speaking classes. }\end{array}$ & $27(67.5)$ & $13(32.5)$ \\
\hline
\end{tabular}


Table 4 reveals that $(77.5 \%)$ respondents stated that the materials in speaking classes were exciting for developing your speaking skills, and a greater number of them (87.5\%) agreed that the activities in speaking classes empowered them to speak English. However, only $25 \%$ agreed that the learning facilities in speaking classes were appropriate. These findings indicated that the activities and materials used in speaking classes were suitable enough for the students, but the facilities for learning speaking in the classroom need to be improved. They were strengthened by the data obtained through interviews, as indicated in the following excerpts.

Table 4: Speaking Materials, Activities, and Facilities

\begin{tabular}{|c|l|c|c|}
\hline \multirow{2}{*}{ No. } & \multicolumn{1}{|c|}{ Statements } & Yes & No \\
\cline { 3 - 4 } & & $\mathbf{f}(\boldsymbol{\%})$ & $\mathbf{f}(\boldsymbol{\%})$ \\
\hline 1 & $\begin{array}{l}\text { The materials in speaking } \\
\text { classes are exciting for } \\
\text { developing your speaking skills. }\end{array}$ & $31(77.5)$ & $9(22.5)$ \\
\hline 2 & $\begin{array}{l}\text { The activities in speaking } \\
\text { classes empowered you to speak } \\
\text { English. }\end{array}$ & $35(87.5)$ & $5(12.5)$ \\
\hline 3 & $\begin{array}{l}\text { The learning facilities in } \\
\text { speaking classes are appropriate. }\end{array}$ & $10(25)$ & $30(75)$ \\
\hline
\end{tabular}

I think the learning materials we used to have in speaking classes were interesting. Humm... the materials were organized in good gradation, the easiest is in Speaking one and the most difficult in Speaking four. The activities were also good. New expression drills, discussion, interview, reporting, and role-play are advantageous activities, I think. ... The only thing necessary to improve is probably the learning facilities. You know, I think, it will be advantageous if we could have modern audiovisual equipments in speaking classes. (Interviewee B).

The learning materials were interesting enough, I think. They challenged me not only to learn new expressions but also to practice using them. The activities were O.K., too. But the learning facilities need to be improved. In my opinion, the learning process will be more interesting if we could have modern audiovisual equipments in speaking classes. (Interviewee C)

The distribution of the respondents' views concerning with the use of English in classroom interactions revealed that only $27.5 \%$ of them always communicated in English with class fellows and $62.5 \%$ with lecturers. These 
findings, which indicated that the frequency of using English to communicate with lecturers was far higher than the frequency with classmates, revealed the possibility that the respondents should be "forced" to practice English. They spoke in English with lecturers because they were expected to do so. The implication of these findings is that the study program needs to create programs which necessitate the use of English as a means of communication among the students.

The respondents' views on the psychological barriers to speaking mastery revealed that most of them $(60.00 \%)$ were shy to speak English because of their classmates laughing and almost one-third $(32.50 \%)$ did not speak in English because they were afraid of their lectures. This fear was possibly due to lecturers scolding when they spoke incorrectly, as stated by $47.50 \%$ of respondents (see table 5). As indicated by the data obtained through interviews, the respondents did admit that the scolding was basically intended to correct their utterances errors. However, since it turned to be a debilitative factor in the trials to develop students' speaking mastery, it is urgent for lecturers to find more acceptable ways to correct students' error in speaking. Patil (2008) asserts that building up the learner's confidence to eliminate fear of making errors was a priority the teacher should consider in order to make the learner feel comfortable with their language use.

Table 5: Classroom Climate and Students' Psychological Barriers

\begin{tabular}{|c|l|c|c|}
\hline \multirow{2}{*}{ No. } & \multicolumn{1}{|c|}{ Statements } & Yes & No \\
\cline { 3 - 4 } & \multicolumn{1}{|c|}{$\mathbf{f ( \% )}$} & $\mathbf{f}(\%)$ \\
\hline 1 & $\begin{array}{l}\text { You always use English in all } \\
\text { interactions with class mates in } \\
\text { all class interactions. }\end{array}$ & $11(27.5)$ & $29(72.5)$ \\
\hline 2 & $\begin{array}{l}\text { You always communicate in } \\
\text { English with lecturers in all } \\
\text { speaking and non-speaking } \\
\text { classes. }\end{array}$ & $25(62.5)$ & $15(37.5)$ \\
\hline 3 & $\begin{array}{l}\text { Shy to speak English due to } \\
\text { laughing of classmates. }\end{array}$ & $24(60)$ & $16(40)$ \\
\hline 4 & $\begin{array}{l}\text { Lecturers scold when you speak } \\
\text { incorrectly. }\end{array}$ & $19(47.5)$ & $21(52.5)$ \\
\hline 5 & $\begin{array}{l}\text { Do not speak because of feeling } \\
\text { afraid of lecturer. }\end{array}$ & $13(32.5)$ & $27(67.5)$ \\
\hline
\end{tabular}


To speak well and fluently in English, you must use it as often as possible, and I believe using it to communicate with friends is one of the best ways. Unfortunately friends of mine still feel afraid of being looked foolish when they commit errors. I often told them that committing errors in learning a foreign language is common. Thus, in one hand, we should not feel shy when we make errors, and, on the other hand, we should not laugh at someone when he makes errors. But some of them prefer to live in their comfort zone. ... I love interacting in English with my lecturers. While talking with them, I always learn new ways to express something. I made them a kind of mirror that reflects my English. So, their corrections are feedbacks for me. Why should I be afraid of them? (Interviewee A)

We, students, realize talking one to another is a kind of good practice. But we often feel securer to exchange ideas and information in bahasa Indonesia. I don't like to take the risk of being laughed by classmates or being corrected by the lecturers too often. If I make errors too often, won't the lecturers reduce my score? (Interviewee B)

Using English to interact with classmates is very advantageous to develop my speaking competence. I love doing it during class hours. Unfortunately, not all friends of mine think the same way. Some of them often reply me in Indonesian. They feel uncomfortable to be looked foolish when they make errors. ... Communicating with lecturers in English is the best chance to develop your speaking skill and getting new knowledge as well. For me, error corrections from lecturers are good feedbacks. Yes, I accepted them positively for they make my expressions better. (Interviewee D)

I know that using English to interact with classmates is a good practice to develop my speaking competence. However, not all classmates are mature enough to hear errors. That's why some of us prevent exchanging ideas in English. ... Talking to lecturers in English is compulsory because we are studying English. Unfortunately, some lecturers need to be more tactful in correcting our errors. I hope all lecturers understand some students are very sensitive. (Interviewee E)

\section{Conclusions}

According to the data, only $45 \%$ of the respondents knew thought their speaking mastery high. The other 55\% did not think so. However, since all respondents stated that they wanted to speak English well and fluently, it can be safely concluded that for them speaking is very important to master. In relation 
to this, more than a half of them were willing to deal with necessary activities, including presenting papers at seminars, joining speech contests and debate competitions, in order to master it.

A majority of the respondents agreed that the opportunity they got for improving speaking in speaking classes was appropriate. Most of them also stated that materials in speaking classes are exciting and the activities were varied and interesting. However, they thought that the time provided was too limited and the learning facilities need to be improved.

Although more than a half the respondents stated they also got proper opportunity to speak English in non-speaking classes, a bigger number of them still insisted on having more intensive use of English in non-speaking classes. Therefore, lecturers in non-speaking class need to make their class more interactive or student-centered. By doing so, the students will get greater opportunity to practice speaking as a tools for learning. They do not only learn about English but also learn to use it in a natural way during the classes.

Some respondents felt they were sometimes scolded by their lecturers for speaking incorrectly, but more than half did not think so. Some of them did not speak English in the classrooms because of fearing of their teachers. In addition, more than a half of the respondents felt shy to speak in English because of fearing of their class fellows' laughing. These findings indicated that the students should be given motivation, encouragement, some psychological training, reassurance and counseling for removing their shyness due to laughing of their class fellows and scolding by their lecturers. The lecturers also need to find more friendly ways to correct the students' error. In short, providing a friendly and conducive environment in the classroom should be made a priority.

\section{References}

Applegate, R. (1975) 'The language teacher and the rules of speaking.' TESOL Quarterly 9(3), 271-281.

Bailey, M. K.. (2002) Issues in teaching speaking skills to adult ESOL learners, Cambridge University Press.

Brown, D. (2001) Teaching by principles: An interactive approach to language pedagogy (2nd ed.). New York: Longman.

Burnkart, G. S. (1998). "Spoken language: What it is and how to teach it." Retrieved on April 26, 2010 from http://www.nclrc.org/ essentials/ speaking/goalsspeak.htm.

Cane, G. (1998) 'Teaching conversation skills more effectively.' The Korea TESOL Journal 1/1: 31-37.

Celce-Murcia, M., Dörnyei, z. and Thurrell, S. (1997) 'Direct approaches in L2 instruction: A turning point in communicative language teaching?' TESOL Quarterly 31/1: 141-152. 
Crystal, D. (1997). English as a global language. Cambridge: Cambridge University Press.

Dornyei, Z. and Thurrell, S. (1994) 'Teaching conversational skills intensively: course content and rationale.' ELT Journal 48(1), 40-49.

Graves, K. (2008) 'The language curriculum: A social contextual perspective.' Language Teaching 41(2), 147-181.

Gumperz, J. (1999) 'Sociocultural knowledge in conversational inference'. In Jaworski, A. and Coupland, N. (eds.) The Discourse Reader. Oxon: Routledge.

Hayriye, K,. 2006. Teaching speaking: Activities to promote speaking in a second language,' The Internet TESLJournal, (Online), 12(11). Retrieved on December 10, 2009 from .http://iteslj.org/Techniques/ KayieachingSpeaking.

Hinkel, E. (Ed.). 2005. Handbook of research in second language teaching and learning. New Jersey: Lawrence Erlbaum Associates, Inc.

Hybel, R. L. Wr. (2001). Communicating effectively, (New York: Mc GrawHill Higher Education).

Kroeker, R.H. (2009). The reality of english conversation classes: a study in a south korean university. (Master thesis). School of Humanities of the University of Birmingham, Birmingham, United Kingdom

McCarthy, M. (1991). Discourse Analysis for Language Teachers. Cambridge: Cambridge University Press.

Nunan, D. (1991). Language teaching methodology: A textbook for teachers. New York: Prentice Hall.

(1999) Second language teaching and learning. Boston: Heinle and Heinle Publishers.

Patil, Z.N. (2008). Rethinking the objectives of teaching English in asia. Asian EFL Journal.10 (4), 227-240. Retrieved on October 17, 2009 from http://www.asianefl-journal. com/December_08_zn.php

Richards, J. (1980). 'Conversation.' TESOL Quarterly 14(4), 413-432.

Richards, J. C. (1990). Conversationally speaking: Approaches to the teaching of speaking. In Jack C. R, The language teaching matrix. New York: Cambridge University Press.

Richards, J.C. and Renandya, W.A. (Eds). (2002). Methodology in language teaching. Cambridge University Press.

Sayer, P. (2005) 'An intensive approach to building conversational skills.' ELT Journal 59/1:14-22.

Thornbury, S. (1998). 'Comments on Marianne Celce-Murcia, Zoltan Dörnyei, and Sarah Thurrell's "Direct Approaches in L2 Instruction: A Turning Point in Communicative Language Teaching?"' TESOL Quarterly 32/1: 109-116. (2005). How to teach speaking. Essex: Pearson Longman 
Thornbury, S. and Slade, D. (2006). Conversation: from description to pedagogy. Cambridge: Cambridge University Press.

Van Lier, L. (1989). 'Reeling, writhing, drawling, stretching, and fainting in coils: Oral proficiency interviews as conversation.' TESOL Quarterly 23(3), 689-508.

Willis, J. (1996) A framework for task-based learning. Essex: Longman.

Yorio, C. (1980). 'Conventionalized language forms and development of communication competence.' TESOL Quarterly 14/4: 433-442. 